University of Nebraska - Lincoln

DigitalCommons@University of Nebraska - Lincoln

Faculty Publications: Department of Entomology

Entomology, Department of

August 1992

\title{
Assessing Needs for Computer Pest Management Software in Nebraska Agriculture
}

Robert J. Wright

University of Nebraska-Lincoln, rwright2@unl.edu

Follow this and additional works at: https://digitalcommons.unl.edu/entomologyfacpub

Part of the Entomology Commons

Wright, Robert J., "Assessing Needs for Computer Pest Management Software in Nebraska Agriculture" (1992). Faculty Publications: Department of Entomology. 89.

https://digitalcommons.unl.edu/entomologyfacpub/89

This Article is brought to you for free and open access by the Entomology, Department of at DigitalCommons@University of Nebraska - Lincoln. It has been accepted for inclusion in Faculty Publications: Department of Entomology by an authorized administrator of DigitalCommons@University of Nebraska - Lincoln. 


\title{
Assessing Needs for Computer Pest Management Software in Nebraska Agriculture
}

\author{
ROBERT J. WRIGHT 1
}

Department of Entomology, 210 Plant Industry Building, University of Nebraska-Lincoln, Lincoln, Nebraska 68583

\begin{abstract}
J. Econ. Entomol. 85(4):1218-1221 (1992)
ABSTRACT A mail survey was conducted to assess current computer hardware use and perceived needs of potential users for software related to crop pest management in $\mathrm{Ne}$ braska. Surveys were sent to University of Nebraska-Lincoln agricultural extension agents, agribusiness personnel (including independent crop consultants), and crop producers identified by extension agents as computer users. There were no differences between the groups in several aspects of computer hardware use (percentage computer use, percentage IBM-compatible computer, amount of RAM memory, percentage with hard drive, hard drive size, or monitor graphics capability). Responses were similar among the three groups in several areas that are important to crop pest management (pest identification, pest biology, treatment decision making, control options, and pesticide selection), and a majority of each group expressed the need for additional sources of such information about insects, diseases, and weeds. However, agents mentioned vertebrate pest management information as a need more often than the other two groups. Also, majorities of each group expressed an interest in using computer software, if available, to obtain information in these areas. Appropriate software to address these needs should find an audience among all three groups.
\end{abstract}

KEY WORDS Insecta, computer software, pest management, mail survey

EXTENSION EDUCATIONAL materials or programs often are developed without formal assessment of the needs of the group for which they are targeted. Then, after a program has been implemented, studies may be conducted to suggest ways to improve it, or to document program effectiveness (e.g., Rajotte et al. 1987, Wearing 1988). An alternate approach is to assess the needs of the intended audience early in program development and develop programs based on audience needs.

This approach was used at the University of Nebraska-Lincoln by a group of extension specialists, working primarily in the area of crop pest management, as a prelude to development of computer software programs. A mail survey of several potential user groups (agricultural extension agents, crop consultants and other agribusinesses, and crop producers) was conducted to avoid development of software with a limited audience, either because of inadequate computer hardware for running the software, or from lack of interest in use of computer software to address a specific need. The survey results provide information on use of computers in agriculture and the perceived needs for software related to crop pest management.

1 Current address: South Central Research and Extension Center, Box 66, University of Nebraska-Lincoln, Clay Center, Nebr. 68933.

\section{Materials and Methods}

During 1989 and 1990, a mail survey was conducted of three groups: crop producers, agribusiness personnel (including crop consultants), and University of Nebraska-Lincoln extension agents with responsibilities in agriculture. These groups were selected as representatives of several potential users of crop pest management software, although they do not necessarily include all potential users in Nebraska. Questions were asked of all three groups regarding their current computer hardware, their information needs related to crop pest management not met by existing resources, and their interest in use of computer software to address these needs.

The agribusiness group consisted of regular (independent crop consultants, not associated with pesticide sales) and commercial members (agribusinesses, including employees of seed corn companies, pesticide companies, and pesticide dealers and applicators) of the Nebraska Independent Crop Consultant Association (NICCA) during 1988 (there were 37 regular and 30 commercial members of NICCA in 1988). This organization was chosen because of its broad representation of several types of agribusiness in Nebraska. The agent group consisted of all 68 University of Nebraska-Lincoln Cooperative Extension agents with agricultural responsibilities. Agents were asked to identify two crop 
Table 1. Computer use among different groups of potential crop pest management software users in Nebraska as determined by a mail survey

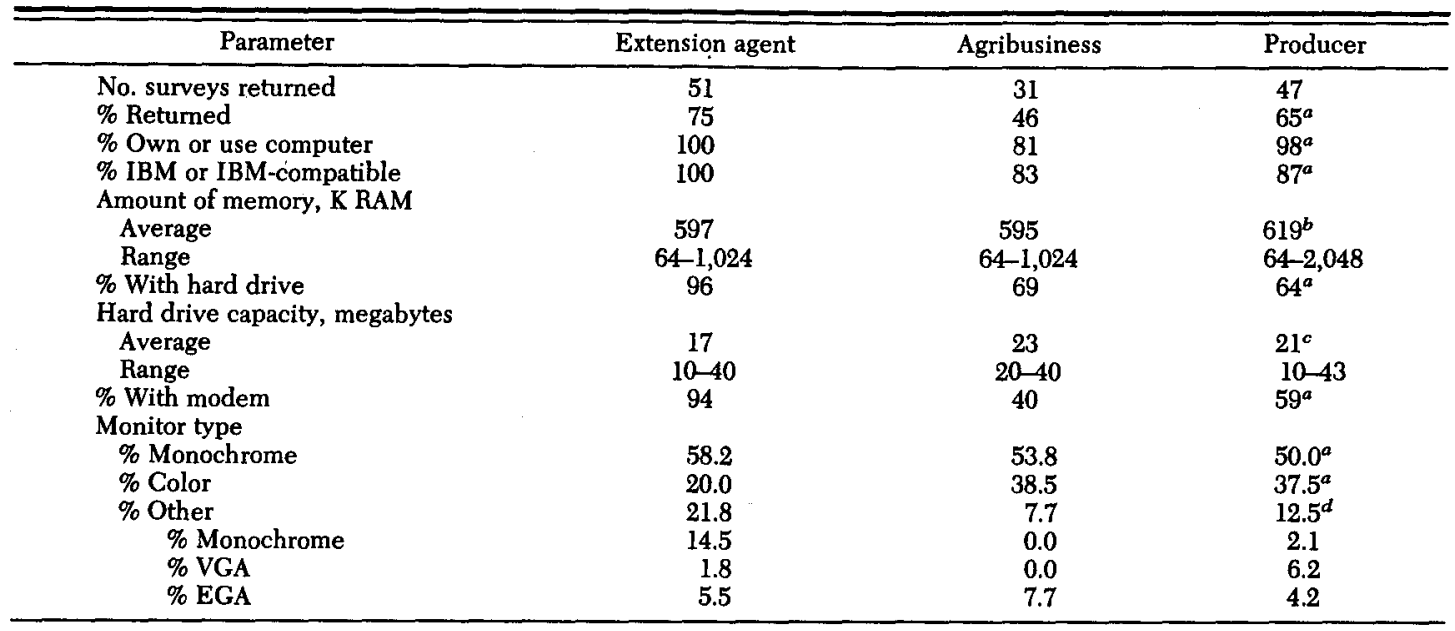

${ }^{a} \chi^{2} \leq 4.63, \mathrm{df}=2, P>0.05$.

${ }^{b} F=0.135 ; \mathrm{df}=2,112 ; P>0.05$.

${ }^{c} F=2.107 ; \mathrm{df}=2,65 ; P>0.05$.

${ }^{d} \chi^{2}=2.5$, df $=1, P>0.05$.

producers in their area who were currently using a computer in their business, and 72 individuals nominated by responding agents comprised the crop producer population. This nonrandom biased sampling was done to ensure that a sufficient number of producers using computers would be obtained in the survey population; currently there are relatively low levels of computer use among some producer populations (e.g., $21 \%$ either owned, leased, or shared a computer according to a 1987 survey reported in Iddings \& Apps [1990], and $25.6 \%$ owned computers according to a 1986 survey by Putler \& Zilberman [1988]). Because a biased sampling procedure was used, the crop producer group surveyed is not representative of all growers.

A questionnaire was developed with both closed- and open-ended questions. There were five questions, although several of these had several parts. The survey was sent to all three groups with a cover letter that described the purpose of the survey and a paid, addressed envelope for survey return. Because of the high rate of return, no follow-up mailings were conducted. A copy of the survey questionnaire is available from the author upon request.

Differences in responses among the three groups (agricultural extension agents, agribusinesses [including crop consultants], and crop producers) were determined by use of the $\chi^{2}$ statistic for count data and analysis of variance for measurement data (Little \& Hills 1978). When computing the $\chi^{2}$, categories with less than five expected responses were pooled, and Yate's correction was used to calculate $\chi^{2}$ with df $=1$ (Little \& Hills 1978). The null hypothesis for all tests was that there were no differences between the groups in their responses to individual questions. The significance level for all comparisons was $\alpha=0.05$.

\section{Results and Discussion}

There were no statistically significant differences among the three groups in several responses related to computer hardware use (Table 1). (All questions reported in Tables 1 and 2 were closed-ended and are shown exactly as worded on the questionnaire.) From 80 to $100 \%$ of the individuals who responded to the survey owned or used a computer (however, the producer group was preselected to include only individuals thought to use computers). All three groups primarily ( $>80 \%$ ) owned IBM or IBM-compatible computers and had similar amounts of RAM memory $(603 \pm 20.5 \mathrm{~K}[x \pm \mathrm{SE}])$. Computers that were not IBM compatible consisted primarily $(\approx 90 \%)$ of Apple II models, and the remainder were MacIntosh models. A majority of each group had computers with hard drives with similar capacities (19 \pm 1.1 megabytes), and also had modems.

Individuals were asked to report the model name of the computer used. Where sufficient information was provided, the computer chip and speed was inferred from the model information. From all three groups, of 63 respondents who provided sufficient information, $50.8 \%$ had models with 8086 chips, $17.4 \%$ had 8088 chips, $28.6 \%$ had 80286 chips, and $3.2 \%$ had 80386 chips; $68.3 \%$ had computers with $4.7 \mathrm{MHz}$ speed, $22.2 \%$ had $10 \mathrm{MHz}, 6.3 \%$ had $12 \mathrm{MHz}$, and $3.2 \%$ had $20 \mathrm{MHz}$.

The reported needs for pest management information did not differ significantly among 
Table 2. Perceived needs among three potential user groups in Nebraska for crop pest management information and software as determined by a mail survey

\begin{tabular}{|c|c|c|c|}
\hline \multirow[b]{2}{*}{ Subject area } & \multicolumn{3}{|c|}{$\%$ Positive responses } \\
\hline & $\begin{array}{l}\text { Extension } \\
\text { agent }\end{array}$ & Agribusiness & Producer \\
\hline \multicolumn{4}{|c|}{$\begin{array}{l}\text { Question: What types of questions do you have difficulty } \\
\text { answering with the current resources available to you? } \\
\text { Check all that apply. }\end{array}$} \\
\hline \multicolumn{4}{|c|}{ Pest identification } \\
\hline Weeds & 54.9 & 41.9 & $48.9^{a}$ \\
\hline Insects & 58.8 & 41.9 & $59.6^{a}$ \\
\hline Diseases & 78.4 & 77.4 & $55.3^{a}$ \\
\hline Vertebrates & 39.2 & 3.2 & $8.5^{b}$ \\
\hline \multicolumn{4}{|c|}{ Pest biology (pest life cycle and behavior) } \\
\hline Weeds & 35.3 & 41.9 & $42.6^{\circ}$ \\
\hline Insects & 58.8 & 54.8 & $61.7^{a}$ \\
\hline Diseases & 60.8 & 71.0 & $53.2^{a}$ \\
\hline Vertebrates & 31.4 & 0 & $10.6^{c}$ \\
\hline \multicolumn{4}{|c|}{$\begin{array}{c}\text { Treatment decision-making (damage symptoms, when and } \\
\text { how to sample, action thresholds) }\end{array}$} \\
\hline Weeds & 62.7 & 58.1 & $59.6^{a}$ \\
\hline Insects & 80.4 & 48.4 & $74.5^{a}$ \\
\hline Diseases & 76.5 & 61.3 & $55.3^{a}$ \\
\hline Vertebrates & 43.1 & 0 & $12.8^{d}$ \\
\hline \multicolumn{4}{|c|}{$\begin{array}{c}\text { Control options for specific pests (chemical and } \\
\text { nonchemical) }\end{array}$} \\
\hline Weeds & 66.7 & 80.6 & $61.7^{a}$ \\
\hline Inse & 76.5 & 64.5 & $66.0^{\circ}$ \\
\hline Diseases & 60.8 & 51.6 & $53.2^{a}$ \\
\hline Vertebrates & 39.2 & 0 & $14.9^{e}$ \\
\hline \multicolumn{4}{|c|}{ Pesticide selection (economics, efficacy, label restrictions) } \\
\hline Weeds & 70.6 & 80.6 & $63.8^{a}$ \\
\hline nsects & 68.7 & 67.7 & $61.7^{a}$ \\
\hline Diseases & 56.9 & 48.4 & $42.6^{a}$ \\
\hline \multicolumn{4}{|c|}{ Other topics } \\
\hline $\begin{array}{l}\text { Irrigation scheduling } \\
\text { Fertilizer use }\end{array}$ & $\begin{array}{l}25.5 \\
66.7\end{array}$ & $\begin{array}{l}45.2 \\
45.2\end{array}$ & $\begin{array}{l}44.7^{a} \\
74.5^{a}\end{array}$ \\
\hline \multicolumn{4}{|c|}{$\begin{array}{l}\text { Question: If micro-computer based programs were } \\
\text { developed to assist you in answering the types of } \\
\text { questions described above, would you use them? }\end{array}$} \\
\hline & 83.3 & 71.0 & $80.9^{a}$ \\
\hline \multicolumn{4}{|c|}{$\begin{array}{l}\text { Sample size of each potential user group is shown in Table } 1 . \\
{ }_{a} \chi^{2} \leq 3.13, \mathrm{df}=2, P<0.05 \\
{ }^{b} \chi^{2}=17.33, \mathrm{df}=2, P<0.001 \\
{ }^{c} \chi^{2}=13.19, \mathrm{df}=2, P<0.01 \\
{ }_{d} \chi^{2}=19.13, \mathrm{df}=2, P<0.001 \\
\chi^{e} \chi^{2}=15.38, \mathrm{df}=2, P<0.001 \\
{ }^{f} \chi^{2}=15.58, \mathrm{df}=2, P<0.001\end{array}$} \\
\hline
\end{tabular}

groups (Table 2), except in relation to vertebrate pests. On several questions, agents most frequently mentioned information on vertebrate pests as a need. Producers mentioned vertebrate pests less frequently, and agribusiness personnel mentioned vertebrate pest information least frequently as a need. However, for several aspects of pest management, information on diseases, insects, and weeds was commonly listed by all three groups as a need not being met adequately by available resources.

There were no significant differences among the three groups concerning interest in use of computer software programs, if available, to address the above information needs related to crop pest management (Table 2). A majority
(>70\%) of all three groups expressed interest. Individuals who expressed no interest in use of computer software programs were asked to indicate a reason, either by checking any of three suggested reasons ("Don't have convenient access to computer where I work," "Need to answer questions in the field not from the office," and "Don't like to use computers"), or by writing a reason of their own. The first two suggested reasons were chosen commonly (data not shown), but no one agreed that not liking to use computers was a reason for lack of interest in use of software programs. Other reasons listed included concerns about cost, accuracy, and time needed to run a program.

Space was provided for respondents to write additional comments. Some of these comments also provided useful ideas. For example, extension agents and agribusiness personnel suggested the formation of an advisory committee to provide guidance on program content. This reflected a concern that software would be developed with inflexible recommendations or unrealistic assumptions that they could not modify. One extension agent suggested that because these programs may not be used on a day-to-day basis, and would probably not be used at all during the winter, programs should be simple enough to be relearned quickly after periods of no use.

This survey has documented that many perceived needs for crop pest management information are similar among three important current and potential users of computer software. In several areas important to pest management (pest identification, pest biology, treatment decision making, control options, and pesticide selection), a majority of each group expressed the need for additional sources of such information dealing with insects, diseases, or weeds. Appropriate software to address these needs should find an audience among all three groups. Documented interest by the groups in use of computer programs may be useful in generating financial support for program development.

Considering the resources needed to develop effective software, which perceived needs are best addressed by program development? Some perceived needs (such as information on pest identification) may be addressed better by existing resources such as color picture sheets and extension publications. Other perceived needs, particularly those that require complex data management or computational efforts (e.g., calculation of economic thresholds or selection of pesticides based on cost, efficacy, and label restrictions), may be more suitable topics for software development.

Survey results (Table 1) indicate limited graphic capabilities of many computers currently used. Also, the majority of computers had 8086 or 8088 chips and were relatively slow in computa- 
tional speed. Software programs that required high-resolution graphics (for example, pest identification programs) could not be run on many computers in use by the groups surveyed. Also, programs may take long periods of time to run on most of the computers reported by the survey respondents.

One limitation in using this information is that it reflects past conditions (survey responses were from late 1989 and early 1990). Computer hardware is frequently upgraded and supplemented by the groups surveyed. By the time a new software program was released, there could be significant changes in some aspects of the hardware used by these groups (e.g., graphic capabilities, computer speed, hard drives, or modems). However, some factors (such as IBM or IBMcompatible versus Apple or Macintosh use) are less likely to change greatly in a few years, because of the greater expense involved. Additionally, this study primarily dealt with current computer users. If computer use is to expand in the future, the characteristics of nonusers should be considered as well (Audirac \& Beaulieu 1986, Iddings \& Apps 1990).

\section{Acknowledgment}

I thank Roger Gold and Shripat Kamble (University of Nebraska-Lincoln) for partial financial support of this survey; Larry Godfrey and Leon Higley (University of Nebraska-Lincoln) for helpful suggestions after review of an earlier version of the manuscript; Ron Seymour and Mary Nelson (University of NebraskaLincoln) for assistance in compiling the survey responses; and Dale Fangmeier, Ron Johnson, Shripat Kamble, Alex Martin, Larry Schulze, and Dave Wysong (University of Nebraska-Lincoln) for suggestions on the survey questions. This is paper no. 9349 of the Journal Series of the Nebraska Agricultural Research Division and contribution no. 741 of the Department of Entomology, University of Nebraska-Lincoln.

\section{References Cited}

Audirac, I. \& L. J. Beaulieu. 1986. Microcomputers in agriculture: A proposed model to study their diffusion/adoption. Rural Sociol. 5: 60-77.

Iddings, R. K. \& J. W. Apps. 1990. What influences farmers' computer use? J. Ext. 28: 19-21.

Little, T. M. \& F. J. Hills. 1978. Agricultural Experimentation-Design and Analysis. Wiley, New York.

Putler, D. S. \& D. Zilberman. 1988. Computer use in agriculture: Evidence from Tulare County, California. Am. J. Agric. Econ. 70: 790-802.

Rajotte, E. J., R. F. Kazmierczak, Jr., G. W. Norton, M. T. Lambur \& W. A. Allen. 1987. The national evaluation of extension integrated pest management (IPM) programs. Virginia Cooperative Extension Service Publication 419-010.

Wearing, C. H. 1988. Evaluating the IPM implementation process. Annu. Rev. Entomol. 33: 17-38.

Received for publication 19 September 1990; accepted 27 January 1992. 